\title{
NCOA2 wt Allele
}

National Cancer Institute

\section{Source}

National Cancer Institute. NCOA2 wt Allele. NCI Thesaurus. Code C52136.

Human NCOA2 wild-type allele is located in the vicinity of $8 q 13.2$ and is approximately $292 \mathrm{~kb}$ in length. This allele, which encodes nuclear receptor coactivator 2 protein, is involved in the transcriptional activation mediated by both steroid and hormone receptors. 